\title{
Mercury in grain size fractions of aggregates and extractive waste from hard coal mining
}

\section{Introduction}

The occurrence of mercury in hard coals and in by-products of mining this mineral (aggregates or extractive waste) is well known and documented in the literature. However, the level of the content of this element in raw materials or waste as well as the search for the dependence between its occurrence and the content of other compounds or pollutants are important. The concentration of mercury in coals varies. The content of this element in hard coal, measured and published in an earlier work (Klojzy-Karczmarczyk and Mazurek 2013), ranges from 0.003 to $0.303 \mathrm{mg} / \mathrm{kg}$, while its average value is $0.074 \mathrm{mg} / \mathrm{kg}$. Studies and analyzes conducted by other authors (Bojakowska and Sokołowska 2001; Chmielniak et al. 2012; Michalska and Białecka 2012; Okońska et al. 2013; Wichliński et al. 2013a; Dziok et al. 2014) indicate that in the existing hard coal mines in Poland, the mercury content in coal is within the wide limits of $0.001-0.967 \mathrm{mg} / \mathrm{kg}$, assuming an average value of $0.091 \mathrm{mg} / \mathrm{kg}$. Studies in the literature on mercury content in extractive waste are less numerous. Values are given for the extractive wastes from the USCB (Table 1) range between 0.006 and $0.380 \mathrm{mg} / \mathrm{kg}$, with an average value of $0.087 \mathrm{mg} / \mathrm{kg}$ (Michalska and Białecka 2012; Bzowski and Dawidowski 2013; Dziok et al. 2015; Klojzy-Karczmarczyk et al. 2016a; Klojzy-Karczmarczyk et al. 2016d; Wichliński et al. 2016). Mercury in coals (and thus in waste) can be bound to

\footnotetext{
* Ph.D. Eng., Mineral and Energy Economy Research Institute, Polish Academy of Sciences, Krakow, Poland; e-mail: beatakk@min-pan.krakow.pl
} 
both organic and mineral substances. The mercury present in the mineral substance is primarily related to sulfides, in particular with pyrite (Dai et al. 2006; Diehl et al. 2004; Dziok et al. 2015; Bielowicz and Misiak 2016).

Mercury is present in hard coal, but so are a number of other ecotoxic substances and pollutants. Its combustion can therefore lead to the introduction of various pollutants into the environment (eg. Hławiczka et al. 2001; Mazur et al. 2004; Lorenz 2005; Smoliński 2007; Olkuski et al. 2010; Stala-Szlugaj 2011; Kowalik and Zajemska 2013; Antoszczyszyn and Michalska 2016), although there are methods allowing for restricting this process (ie. Aleksa et al. 2007; Wichliński et al. 2011; 2012; Chmielniak and Łukowicz 2012; Zajusz-Zubek and Konieczyński 2014; Dziok and Strugała 2016). Coal mining is also a process in which a significant amount of waste material is produced. In recent years, the economic importance of by-products accompanying coal production has changed and now more and more often they are treated not as waste but as a source of mineral resources for economic use. These materials exhibit the characteristics of an accompanying mineral (Galos and Szlugaj 2010, 2014). However, some of the extracted waste has already been stored in the environment or is still being stored due to the lack of sufficient economic use. Facilities for the disposal of extractive waste represent a potential threat to the environment due to the nature of the waste and its physicochemical properties (eg. Kosa and Kicińska 2016; Klojzy-Karczmarczyk and Mazurek 2014; Jabłońska-Czapla et al. 2014, 2015; Klojzy-Karczmarczyk et al. 2016d).

However, hard coal, despite the environmental burden associated with its extraction, as well as the possibility of introducing pollutants as a result of its combustion, is a basic raw material in the process of energy production in Poland and decides about the energy security of our country (ie. Dubiński and Turek 2012; Grudziński 2012; Gawlik ed. 2013; Szczerbowski and Ceran 2017; Kaliski et al. 2014; Grudziński and Stala-Szlugaj 2015). Hard coal production is closely linked to the generation of significant quantities of extractive waste that require further use. It is therefore important to look for new ways of managing waste or parts thereof, types of waste or grain size fraction (grain class) separated from waste. Studies conducted in earlier works have shown that it is possible to obtain a low-sulfur grain fraction so that it can be used in excavations requiring reclamation by filling (Klojzy-Karczmarczyk et al. 2016b; 2016c, Mucha et al. 2016). The purpose of the research presented in this paper is to determine the mercury content in hard coal mining by-products, aggregates or extractive waste. Extractive waste include primarily undeveloped waste rock and coal sludge (coal silt). The research was conducted in individual grading fractions of aggregates. This paper presents the problem of determining the minimum size of rock fractions meeting the specified limits for mercury content and thus safe as aggregate intended for filling post-mining excavations. Measures have also been taken to determine the dependence of mercury and sulfur in the individual aggregate fractions. 


\section{Methodology of research}

Laboratory research included waste material directly from production (mining and processing of rock) from the one of the hard coal mine USCB. Hard coal sludge (after dewatering on filter presses) and a total of 13 aggregates samples were analyzed. The samples were taken according to their own procedure. Aggregate samples were collected during the full year (October 2014-October 2015) in the whole grain range (general samples directly from the conveyor belt), with samples taken at 2-3 week intervals. That 16 samples of rock material weighing about $200 \mathrm{~kg}$ each and one sample of about $100 \mathrm{~kg}$ were collected. The analysis covered samples numbered from 4 to 16 . For samples 1 to 3 , no analysis was conducted due to the insufficient amount of material. The general samples collected were dissociated into 15 grain size fractions (grain class) in the range of: $0-6,6-8,8-10,10-16$, $16-20,20-25,25-30,30-35,35-40,40-50,50-60,60-80,80-120,120-200 \mathrm{~mm}$ and above $200 \mathrm{~mm}$ (no fraction greater than $200 \mathrm{~mm}$ was found in the test samples). The total mercury content in the analytical state $\left(\mathrm{Hg}^{\mathrm{a}}\right.$ in $\left.\mathrm{mg} / \mathrm{kg}\right)$ was determined in every fraction of all 13 samples. The analysis covered material that had already been tested in another study and the results were published in 2016 (Klojzy-Karczmarczyk et al. 2016a, 2016b, 2016c; Mucha et al. 2016).

Samples of aggregates of various grain sizes were reduced to laboratory samples and subjected to crushing and blending to prepare analytical samples (particle size $<0.2 \mathrm{~mm}$ ). The total mercury content was determined for all of collected samples. Two assays were made for each sample taken and the value reported is the arithmetic mean of the measurements conducted. The standard deviation (SD) is in the range from 0.09 to $1.90 \%$ against the average value. A modification of the classical atomic absorption spectrometry (AAS) method was used to measure the threshold (order of magnitude of nanograms) of mercury in solid and liquid samples of different origins. The advantage of the methodology used is the possibility of eliminating the initial sample preparation stage. The sample mineralization takes place inside the analyzer, just before the detection process. This allows the mercury losses that are always present in classical analytical methods to be minimized. Altec's dedicated AMA-254 atomic absorption spectrometer was used for the study.

The obtained results of mercury content in individual waste fractions were compared to the requirements for the inert extractive waste (Journal of Laws of 2011, No 175, item 1048). This regulation distinguishes a number of parameters and their corresponding contents, which allow waste to be classified as safe for the environment, health and human life. In the case of mercury, it can be concluded from this regulation that the safe total mercury content in soils should not exceed $2 \mathrm{mg} / \mathrm{kg}$ of dry matter, whereas in areas protected under the Water Law, this value is $0.5 \mathrm{mg} / \mathrm{kg}$ of the dry matter (Journal of Laws of 2002, No. 165, item 1359; Journal of Laws of 2016, item 1395). 


\section{Analysis of the mercury studies}

\subsection{Determination of mercury content in coal sludge}

Coal sludge (silt) produced during the coal-enrichment process in the processing plants of hard coal mines and are the smallest grades of a particle size of less than $1 \mathrm{~mm}$, where grades below $0.035 \mathrm{~mm}$ represent up to $60 \%$ of the grain size (Feliks 2012). The tested material was obtained after dewatering on filter presses, the so-called filtration cakes. The mercury determination method used in the study allowed its content to be identified in the range of 0.0568 to $0.0787 \mathrm{mg} / \mathrm{kg}$, on average $0.0649 \mathrm{mg} / \mathrm{kg}$ (in the analytical state $\mathrm{Hg}^{\mathrm{a}}$ ) (Table 1). Taking the average moisture content of samples at $4.3 \%$ the mercury content in the coal sludge in the dry state $\left(\mathrm{Hg}^{\mathrm{d}}\right)$ can be determined, which, on average, was calculated at $0.0678 \mathrm{mg} / \mathrm{kg}$ of dry matter. In the work of 2016 (Klojzy-Karczmarczyk et al. 2016a) for the same waste material, the determined mercury content was significantly lower, below $0.01 \mathrm{mg} / \mathrm{kg}$, which is most likely due to the test method used and the mineralization of the sample in the microwave mineralizer, outside the measuring device. The measured mercury content makes it possible to classify coal sludge as inert extractive waste in view of the size of this parameter (Journal of Laws of 2011, No 175, item 1048).

Table 1. Determination of mercury content in coal sludge in the analyzed samples

Tabela 1. Wyniki badań zawartości rtęci w analizowanych mułach węglowych

\begin{tabular}{|c|c|c|c|c|}
\hline \multirow{2}{*}{ Waste type } & \multicolumn{3}{|c|}{$\mathrm{Hg}$ total content $\mathrm{Hg}^{\mathrm{a}}[\mathrm{mg} / \mathrm{kg}]$} & \multirow{2}{*}{$\begin{array}{c}\text { Number of } \\
\text { samples }\end{array}$} \\
\cline { 2 - 5 } & $\min$ & $\max$ & average & 6 \\
\hline Coal sludge & 0.0568 & 0.0787 & 0.0649 & 6 \\
\hline
\end{tabular}

$\mathrm{Hg}^{\mathrm{a}}[\mathrm{mg} / \mathrm{kg}]$ - total mercury in analytical state (sample moisture average $4.3 \%$ ).

\subsection{Study of mercury content in the individual grain size fractions of aggregates}

The total mercury content of all the grain size fractions extracted from 13 samples of aggregates showed a high variation in the content of this element (Table 2). A noticeable tendency of decreasing mercury content along with the increase in grain size was observed (Fig. 1, 2). The lowest mercury content of 0.0136 to $0.0451 \mathrm{mg} / \mathrm{kg}$ is found in the fraction of $120-200 \mathrm{~mm}$. On the contrary, the highest mercury content of 0.1000 to $0.8966 \mathrm{mg} / \mathrm{kg}$ is obtained in the fraction of $0-6 \mathrm{~mm}$. The average values of total mercury content decrease from $0.4030 \mathrm{mg} / \mathrm{kg}$ for the finest fraction $(0-6 \mathrm{~mm})$ to $0.0291 \mathrm{mg} / \mathrm{kg}$ for the thickest fraction 
(120-200 mm) (Table 2, Fig. 2). The mercury content in the individual fractions of the aggregates was determined in the analytical state $\left(\mathrm{Hg}^{\mathrm{a}}\right)$. The moisture of the samples was determined at about $1 \%$. With such low moisture values, it can be assumed that the mercury content in the analytical state is close to the mercury content in the dry state $\left(\mathrm{Hg}^{\mathrm{d}}\right)$.

Taking all the values obtained into account, it can be stated that they do not exceed the values of safety for the environment and human health both for group B in accordance with the 2002 Regulation (Journal of Laws 2002 No. 165, Item 1359) as well as for groups I-IV determined by the way they are used in a given area in accordance with the 2016 Regulation (Journal of Laws of 2016, Item 1395). Only the finest separated fractions (0-8 mm) are characterized by single values exceeding the safe limits for Group A, ie. for areas protected in accordance with the Water Law. In general it can be stated that the analyzed samples of coal muds meet the criteria for inert mining waste with respect to the mercury content.

The observed tendency of decreasing mercury content along with the increase in grain size is also observed in other materials subjected to environmental tests. An analogous relationship was observed in soils. It can be concluded that the larger the diameter of the grains, the lower the mercury content (Malczyk and Długosz 2009; Klojzy-Karczmarczyk 2014; Kicińska 2017), which is undoubtedly related to the diverse mineralogical composition of individual grain size fractions.

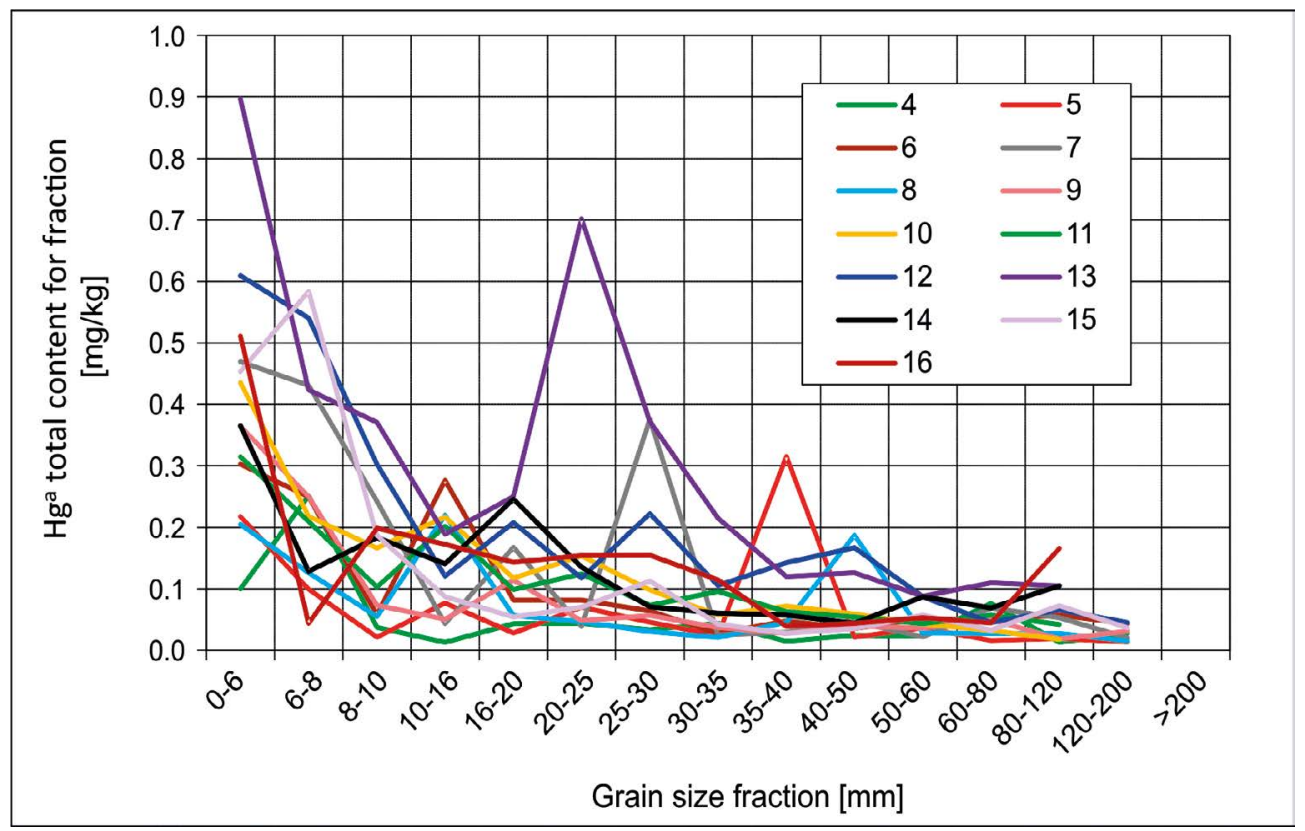

Fig. 1. Distribution of total mercury content in the individual grain size fractions of aggregates (samples of the aggregates collected during one-year period; samples 4-16)

Rys. 1. Rozkład zawartości rtęci w poszczególnych frakcjach ziarnowych kruszyw (próbki kruszyw pobierane w skali roku: próbki 4-16) 
Table 2. Study of mercury content in the individual grain size fractions of aggregates

Tabela 2. Badania zawartości rtęci w poszczególnych frakcjach kruszyw

\begin{tabular}{|c|c|c|c|c|c|c|}
\hline \multirow{2}{*}{$\begin{array}{c}\text { Grain size } \\
\text { fraction } \\
{[\mathrm{mm}]}\end{array}$} & \multicolumn{3}{|c|}{$\begin{array}{c}\text { Fraction share in sample weight } \\
{[\%]}\end{array}$} & \multicolumn{3}{|c|}{$\begin{array}{l}\text { Hg total content in the grain size } \\
\qquad \operatorname{Hg}^{\mathrm{a}}[\mathrm{mg} / \mathrm{kg}]\end{array}$} \\
\hline & $\min$ & $\max$ & average & $\min$ & $\max$ & average \\
\hline$>200$ & 0.0 & 0.0 & 0.0 & - & - & - \\
\hline $120-200$ & 0.0 & 11.6 & 4.7 & 0.0136 & 0.0451 & 0.0291 \\
\hline $80-120$ & 3.1 & 17.8 & 9.6 & 0.0132 & 0.1656 & 0.0586 \\
\hline $60-80$ & 4.6 & 21.8 & 9.3 & 0.0163 & 0.1098 & 0.0523 \\
\hline $50-60$ & 3.4 & 8.6 & 6.0 & 0.0220 & 0.0876 & 0.0506 \\
\hline $40-50$ & 3.6 & 7.3 & 5.9 & 0.0217 & 0.1871 & 0.0680 \\
\hline $35-40$ & 3.0 & 12.2 & 5.2 & 0.0149 & 0.3152 & 0.0771 \\
\hline $30-35$ & 2.9 & 6.2 & 4.5 & 0.0209 & 0.1147 & 0.0669 \\
\hline $25-30$ & 3.5 & 7.6 & 5.8 & 0.0309 & 0.3721 & 0.1316 \\
\hline $20-25$ & 3.3 & 8.1 & 5.6 & 0.0391 & 0.7021 & 0.1376 \\
\hline $16-20$ & 1.9 & 6.9 & 4.8 & 0.0282 & 0.2502 & 0.1237 \\
\hline $10-16$ & 0.7 & 14.8 & 6.6 & 0.0131 & 0.2765 & 0.1391 \\
\hline $8-10$ & 0.2 & 9.1 & 3.0 & 0.0218 & 0.3707 & 0.1538 \\
\hline $6-8$ & 0.3 & 10.2 & 3.9 & 0.0440 & 0.5837 & 0.2736 \\
\hline $0-6$ & 16.3 & 37.4 & 25.1 & 0.1000 & 0.8966 & 0.4034 \\
\hline
\end{tabular}

$\mathrm{Hg}^{\mathrm{a}}[\mathrm{mg} / \mathrm{kg}]$ - total mercury in analytical state (sample moisture average $1 \%$ ).

Table 3 summarizes the results of estimating the mercury content in grain size fraction. The contents estimated as a weighted average in which the weight is the mass share of the fraction. This calculation method reflects the actual grain structure of the general sample and the associated mercury content variability. Calculations were made using the total mercury content in the 15 individual grain size fractions mechanically separated from each general (primary) sample. The table (Table 3) shows the results of calculations of mercury content in the whole grain range and in the range of $10-200 \mathrm{~mm}$ and $20-200 \mathrm{~mm}$. A significant decrease in mercury content in the samples was observed after the fine fractions were discarded (secondary samples), both below $10 \mathrm{~mm}$ and below $20 \mathrm{~mm}$. For the whole grain range, the calculated mercury content of the samples is in the range of 0.0488 $-0.4632 \mathrm{mg} / \mathrm{kg}$, assuming a mean value of $0.1834 \mathrm{mg} / \mathrm{kg}$. These values meet safety criteria for the environment even in protected areas. After discarding the fraction below $10 \mathrm{~mm}$, the 


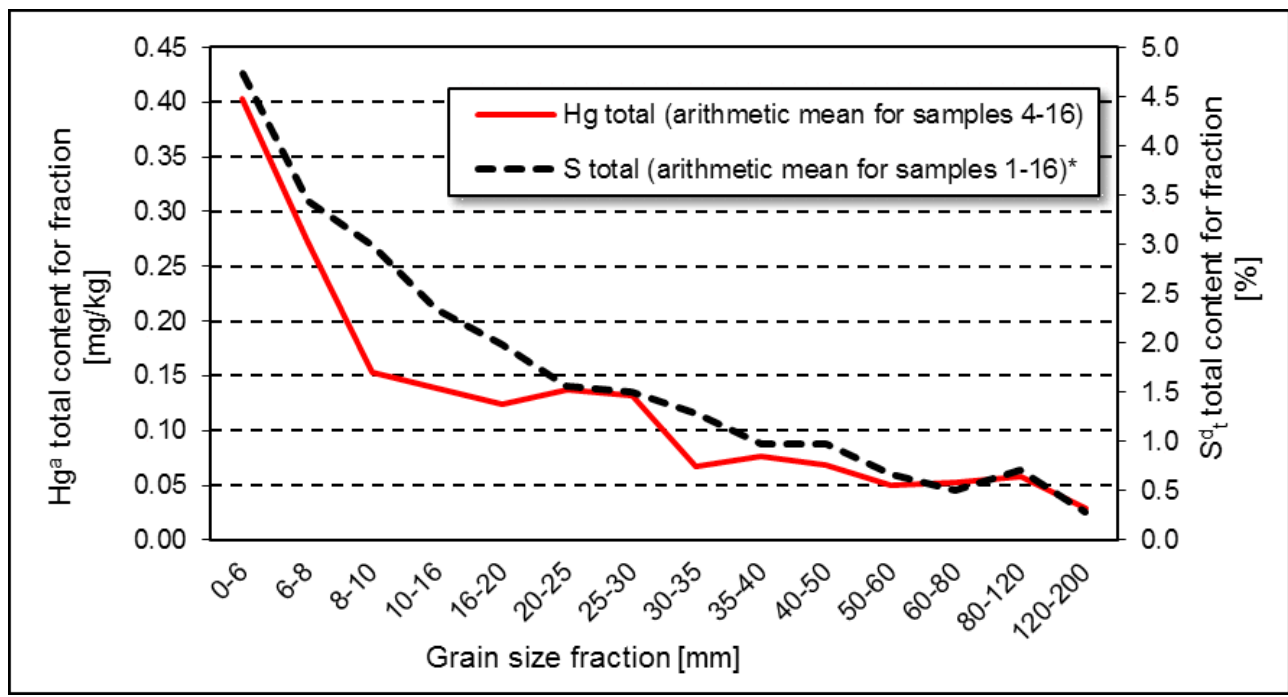

Fig. 2. Coexistence of mercury and sulfur in individual grain size fractions of material * Average content of total sulfur $\left(\mathrm{S}_{\mathrm{t}}{ }^{\mathrm{d}}[\%]\right)$ in fractions according to Klojzy-Karczmarczyk et al. 2016a $\mathrm{a}$ - analytical state, $\mathrm{d}$ - dry state

Rysunek 2. Współwystępowanie rtęci oraz siarki w poszczególnych frakcjach ziarnowych materiału

* Średnia zawartość siarki całkowitej $\left(\mathrm{S}_{\mathrm{t}}{ }^{\mathrm{d}}[\%]\right)$ we frakcjach wg Klojzy-Karczmarczyk i in. 2016a a - stan analityczny, $d$ - stan suchy

mercury content in the samples calculated using a weighted average decreased to an average of $0.0882 \mathrm{mg} / \mathrm{kg}$, and after rejecting the grains below $20 \mathrm{~mm}$ to an average of $0.0744 \mathrm{mg} / \mathrm{kg}$.

This paper presents the problem of determining the minimum size of rock fractions meeting the specified limits for mercury content and thus safe as aggregate intended for filling post-mining excavations. Based on the studies conducted, it can be stated that due to the presence of mercury no separation of fine fractions is necessary, although the removal of waste rock material from the waste below $10 \mathrm{~mm}$ (or even $8 \mathrm{~mm}$ ) significantly increases the quality of this material. Diversification of material due to the size of the grain allows for different ways of waste management.

Measures have also been taken to determine the dependence of mercury and total sulfur in the individual aggregate fractions. Sulfur is the basic characteristic parameter that can be used to assess the suitability of aggregates for use as a fill for reclaimed open-pit excavations (Klojzy-Karczmarczyk et al. 2016c). It is therefore important to obtain material with a low total sulfur content. A significant decrease in the sulfur content was observed in the samples after the fine fractions below $20 \mathrm{~mm}$ were discarded. The sulfur content calculated using a weighted average in such samples is considerably reduced, to the range of $0.4-1.4 \%$, with an average content of $0.8 \%$, which generally satisfies the requirements for inert extractive waste on the assumption that the adequately high neutralising potential ratio values are 
Table 3. Mercury in individual aggregate samples - values calculated in individual grain size intervals

Tabela. 3. Rtęć w poszczególnych próbkach kruszyw - wartości obliczone w poszczególnych przedziałach wielkości ziaren

\begin{tabular}{|c|c|c|c|}
\hline \multirow{2}{*}{$\begin{array}{l}\text { General (primary) sample } \\
\text { number }\end{array}$} & \multicolumn{3}{|c|}{$\mathrm{Hg}$ total content $\mathrm{Hg}_{\text {cal }}^{\mathrm{a}}[\mathrm{mg} / \mathrm{kg}]$ - calculated values* } \\
\hline & $\begin{array}{l}\text { the whole sample } \\
0-200 \mathrm{~mm}\end{array}$ & $\begin{array}{l}\text { grain size } \\
10-200 \mathrm{~mm}\end{array}$ & $\begin{array}{l}\text { grain size } \\
20-200 \mathrm{~mm}\end{array}$ \\
\hline Sample 4 & 0.0488 & 0.0381 & 0.0382 \\
\hline Sample 5 & 0.0809 & 0.0443 & 0.0413 \\
\hline Sample 6 & 0.1399 & 0.0881 & 0.0525 \\
\hline Sample 7 & 0.1771 & 0.0811 & 0.0749 \\
\hline Sample 8 & 0.1044 & 0.0754 & 0.0506 \\
\hline Sample 9 & 0.1307 & 0.0404 & 0.0381 \\
\hline Sample 10 & 0.2053 & 0.1149 & 0.0722 \\
\hline Sample 11 & 0.1476 & 0.0900 & 0.0657 \\
\hline Sample 12 & 0.3195 & 0.1142 & 0.1085 \\
\hline Sample 13 & 0.4632 & 0.2008 & 0.1986 \\
\hline Sample 14 & 0.1762 & 0.0959 & 0.0773 \\
\hline Sample 15 & 0.1703 & 0.0560 & 0.0535 \\
\hline Sample 16 & 0.2197 & 0.1076 & 0.0961 \\
\hline Mean value (samples 4-16) & 0.1834 & 0.0882 & 0.0744 \\
\hline \multicolumn{4}{|c|}{$\begin{array}{l}\text { Total content of } \mathrm{Hg}^{\mathrm{d}}[\mathrm{mg} / \mathrm{kg} \mathrm{DM}] \text { in samples with fixed grain size intervals } \\
\text { (secondary samples) - laboratory tests according to Klojzy-Karczmarczyk et al. 2016a }\end{array}$} \\
\hline Content range & not studied & $<0.0070-0.0248$ & $<0.0059-0.0166$ \\
\hline Mean value & not studied & 0.0146 & 0.0076 \\
\hline
\end{tabular}

* Calculated for the analytical state (sample moisture at $1 \%$ ).

DM - dry matter.

preserved (Klojzy-Karczmarczyk et al. 2016c; Mucha et al. 2016). The preparation of the perspective material from the point of view of lower total sulfur content will simultaneously lead to the reduction of the mercury content to significantly lower values (Table 3).

The studies showed the coexistence of sulfur and mercury in the analyzed grain fractions of the waste material (aggregates) directly from the production (Fig. 2). The statistical analysis revealed correlation between mercury content and total sulfur content (linear coefficient of determination $\mathrm{R}^{2}$ of 0.9151 ) (Fig. 3). Statistical correlation coefficient verification using t-Student's test for significance levels of 0.05 and 0.01 showed significant correlation. 


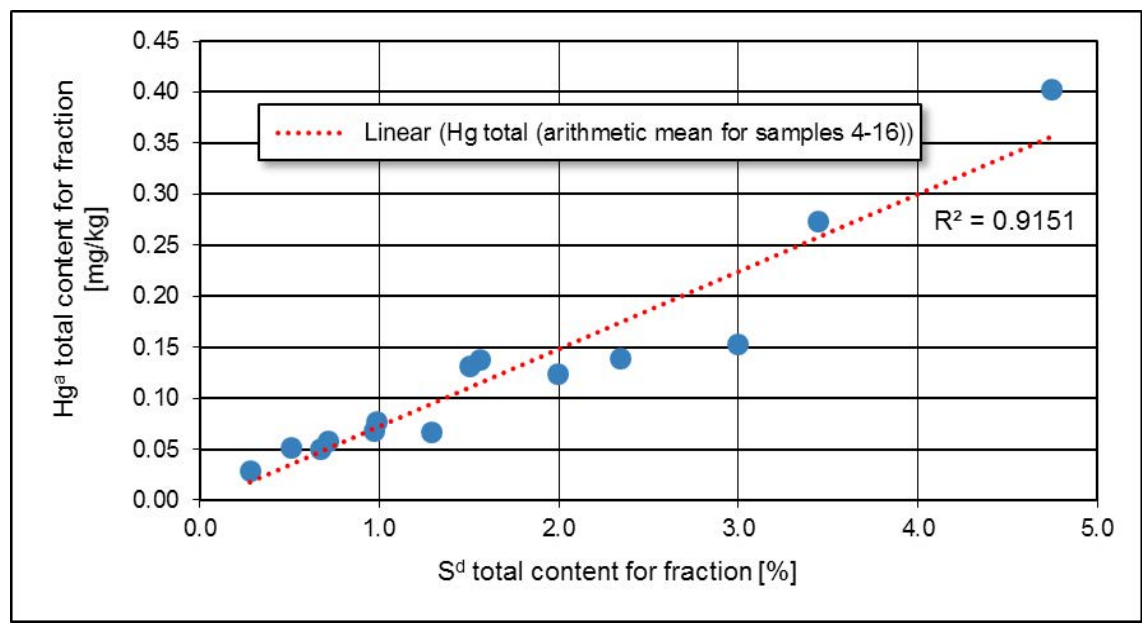

Fig. 3. Correlation of average mercury content with sulfur content in individual grain size fractions of tested samples

(average content of total sulfur according to Klojzy-Karczmarczyk et al. 2016a)

Rys. 3. Korelacja średnich zawartości rtęci z zawartością siarki w poszczególnych frakcjach ziarnowych badanych próbek (średnia zawartość siarki całkowitej wg Klojzy-Karczmarczyk i in. 2016a)

The obtained results and analyses clearly indicate a strong dependence of occurrence of mercury and total sulfur in the material. Similar conclusions were obtained for the coexistence of these elements in the paper by T. Dziok et al. (2015). The results presented in that paper indicate the presence of mercury in pyrite in the waste material (Dziok et al. 2015).

Both studies presented in this paper and in the work by T. Dziok et al. (2015) regard samples of fresh material where no weathering has yet taken place. The situation is different in the case of a mutual correlation between the mercury content and sulfur in the weathered material stored in a dump. Investigations for extractive waste deposited for over 15 years at the dump of the Siersza Coal Mine have shown no correlation between the occurrence of mercury and sulfur in the waste. The lack of correlation between the occurrence of mercury and sulfur may be due to the differences in the processes that govern the transformation and migration of mercury and sulfur compounds which last for many years (Klojzy-Karczmarczyk and Mazurek 2014) as well as the possibility of occurrence of mercury in other mineral components than pyrite.

\subsection{Determination of mercury content in extractive waste according to other authors}

It can be stated that aggregates (waste rock) and coal sludge are characterized by the variable content of total mercury. The analysis of literature data on the presence of mercury in waste materials of Polish hard coal mines (Table 4) showed variability of the content of 
Table 4. Summary of mercury content in extractive waste based on literature (selected data)

Tabela 4. Zestawienie wyników badań zawartości rtęci w odpadach wydobywczych na podstawie literatury (wybrane dane)

\begin{tabular}{|c|c|c|c|}
\hline $\begin{array}{l}\text { Nature of test material, } \\
\text { its origin and source of data }\end{array}$ & $\begin{array}{l}\text { Total content } \\
{[\mathrm{mg} / \mathrm{kg}]}\end{array}$ & $\begin{array}{l}\text { Leachable form } \\
\text { (leaching*) } \\
{[\mathrm{mg} / \mathrm{kg}]}\end{array}$ & Applied instrumental method \\
\hline $\begin{array}{l}\text { By-products of coal extraction (according } \\
\text { to own research presented in the work): } \\
\text { aggregates } 0-200 \mathrm{~mm}(1) \\
\text { coal sludge (2) }\end{array}$ & $\begin{array}{l}0.049-0.463 \\
(\text { av. } 0.183) \\
0.057-0.079 \\
\text { (av. } 0.065)\end{array}$ & - & $\begin{array}{l}\text { Absorptive atomic spectrometry } \\
\text { with amalgamation technique } \\
\text { (AMA 254) }\end{array}$ \\
\hline $\begin{array}{l}\text { Waste from coal mining and processing (1) } \\
\text { as well as from waste from a dump (2) } \\
\text { (according to Michalska and Białecka 2012) }\end{array}$ & $\begin{array}{l}0.006-0.380 \\
(\text { av. } 0.099) \\
0.16\end{array}$ & 0.005 & $\begin{array}{l}\text { Atomic absorption spectrometry } \\
\text { with cold vapor technique } \\
\text { (CVAAS, Nippon MA-2000) }\end{array}$ \\
\hline $\begin{array}{l}\text { Mining waste from the Bogdanka mine } \\
\text { (data from 1996-2012) (according to } \\
\text { Bzowski and Dawidowski 2013) }\end{array}$ & $<1$ & - & $\begin{array}{l}\text { X-ray fluorescence }(\mathrm{XRF}) \\
\text { spectrometry }\end{array}$ \\
\hline $\begin{array}{l}\text { Wastes from coal enrichment in heavy } \\
\text { liquids (1), } \\
\text { jigs (2) and flotation (3) } \\
\text { (according to Dziok et al. 2015) }\end{array}$ & $\begin{array}{c}0.062-0.249 \\
\text { (av. } 0.122) \\
0.055-0.190 \\
\text { (av. } 0.099) \\
0.093-0.148 \\
\text { (av. } 0.121)\end{array}$ & - & $\begin{array}{l}\text { Atomic absorption spectrometry } \\
\text { with cold vapor technique } \\
\text { (CVAAS, Nippon MA-2) }\end{array}$ \\
\hline $\begin{array}{l}\text { Aggregate } 0-200 \mathrm{~mm}(1) \text {, aggregate after } \\
\text { discarding the fine fraction (2) and coal } \\
\text { sludge (3) (according to } \\
\text { Klojzy-Karczmarczyk et al. 2016a) }\end{array}$ & $\begin{array}{c}<0.01-0.01 \\
\text { (av. } 0.01) \\
(2)<0.006-0.025 \\
(\text { av. } 0.011) \\
(3)<0,01\end{array}$ & $\begin{array}{l}<0.001 \\
<0.001 \\
<0.001\end{array}$ & $\begin{array}{l}\text { Inductively coupled plasma - } \\
\text { mass spectrometry (ICP-MS) }\end{array}$ \\
\hline $\begin{array}{l}\text { Mining waste from the dump of the closed } \\
\text { Siersza mine (according to } \\
\text { Klojzy-Karczmarczyk et al. 2016d) }\end{array}$ & $\begin{array}{l}0.06-0.30 \\
\text { (av. } 0.15)\end{array}$ & $\begin{array}{l}0.006-0.017 \\
\quad(\text { av. } 0.01)\end{array}$ & $\begin{array}{l}\text { Absorptive atomic spectrometry } \\
\text { with amalgamation technique } \\
\text { (AMA 254) }\end{array}$ \\
\hline $\begin{array}{c}\text { Coal sludge } \\
\text { (according to Wichliński et al. 2016) }\end{array}$ & $\begin{array}{l}0.015-0.130 \\
(\text { av. } 0.087)\end{array}$ & - & $\begin{array}{l}\text { Atomic absorption spectrometry } \\
\text { with cold vapor technique } \\
\text { (CVAAS, Lumex, RA-915+ with } \\
\text { RP-91C add-on) }\end{array}$ \\
\hline
\end{tabular}

* The stated values were obtained by converting analytical results in 1:10 water extract in $\mathrm{mg} / \mathrm{dm}^{3}$ on the released amount of the contaminating component with respect to the dry matter of the sample and given in $\mathrm{mg} / \mathrm{kg}$ of the sample weight.

this element in both total and removable forms. The observed presence of total mercury varies from the limits of determination to nearly $0.5 \mathrm{mg} / \mathrm{kg}$. The considerable differences observed, however, do not only result from the variability of waste material. Differences in the total assay may be due to differences in test methods used and sample preparation for analysis (sample mineralization). The most accurate results are obtained by atomic absorption 
spectrometry with the internal sample mineralization (AMA 254 spectrometer used, among others). Table 4 shows the highest values for determinations conducted in accordance with this method. The use of mineralization of the solid sample inside the analyzer minimizes the loss of mercury and such analytical techniques are recommended in the literature (Okońska et al. 2013; Wichliński et al. 2013b; Różycka and Rolka 2015; Journal of Laws of 2016, item 1395). The results obtained by inductively coupled plasma - optical emission spectrometry/ /mass spectrometry (ICP OES, ICP MS), due to the mineralization of the sample in the external environment, may be underestimated results.

\section{Summary and conclusions}

Mercury content tests were conducted for individual grain size fractions (grain class) of aggregate (directly from production) and coal sludge (after dewatering on filter presses). The mercury determination method (in the analytical state $\mathrm{Hg}^{\mathrm{a}}$ ) allowed its content in the coal sludge to be identified at $0.0649 \mathrm{mg} / \mathrm{kg}(0.0678 \mathrm{mg} / \mathrm{kg}$ in the dry matter) on average. The obtained mercury content makes it possible to classify coal sludge as inert extractive waste in view of the content of this element.

The analysis of the total mercury content of all fractions separated from the collected 13 general samples of aggregates (waste rock) showed a high variation in the content of this element. A noticeable tendency of decreasing mercury content along with the increase in grain size was observed. The average values of total mercury content decrease from $0.4030 \mathrm{mg} / \mathrm{kg}$ $(0.4070 \mathrm{mg} / \mathrm{kg}$ in the dry matter) for the finest fraction $(0-6 \mathrm{~mm})$ to $0.0291 \mathrm{mg} / \mathrm{kg}(0.0294 \mathrm{mg} / \mathrm{kg}$ in the dry matter) for the thickest fraction $(120-200 \mathrm{~mm})$. In general it can be stated that the analyzed samples of coal sludge and grain fractions aggregates meet the criteria for inert mining waste with respect to the mercury content. Based on the studies conducted, it can be concluded that due to the presence of mercury there is no need to discard fine fractions from aggregates. However, the removal of waste rock material less than $8 \mathrm{~mm}$ significantly increases the quality of the material. The preparation of the perspective material from the point of view of sulfur (by discarding the fine fractions below $20 \mathrm{~mm}$ ) in consequence leads to the reduction of the mercury content to significantly lower values.

In the presented paper measures have also been taken to determine the dependence of mercury and sulfur in the individual aggregate fractions. The obtained results and the conducted statistical analysis clearly indicate a strong correlation between the occurrence of mercury and total sulfur in the material, where no weathering has yet occurred (directly from production). In the case of weathering, however, there is no correlation between the occurrence of mercury and sulfur. This may be due to differences in the processes that govern the transformation and migration of mercury and sulfur compounds spread across many years. The presence of mercury in other than pyrite mineral and organic components can't be excluded.

It should be noted that the applied instrumental method has a significant impact on the determined mercury content. The most accurate results are obtained using the atomic ab- 
sorption spectrometry method with the mineralization of samples inside the device. Such a procedure allows mercury losses at the analysis stage. The study investigates the total mercury content. One cannot forget, however, that the mercury content in leachable form is also decisive for environmental safety, which was not analyzed in this work. However, it can be assumed that, with such values of total mercury content in the test material, the contribution of the leachable form will be small, as previously reported by the author.

An important element in the conducted research is the differentiation of total mercury content in individual grain size fractions. Therefore, it is believed that in the case of mercury content in aggregates or extractive waste, it is necessary to indicate the fraction of the test material for which the analysis was conducted. This suggestion should be taken into account in subsequent studies, and is likely to involve not only mercury and sulfur, but also other elements identified in the waste material from the hard coal mining sector.

The publication was made as part of the statutory works of Mineral and Energy Economy Research Institute PAS

\section{REFERENCES}

Aleksa et al. 2007 - Aleksa, H., Dyduch, F. and Wierzchowski, K. 2007. Chlor i rtęć w węglu i możliwości ich obniżenia metodami przeróbki mechanicznej. Górnictwo i Geoinżynieria Rok 31, z. 3/1, pp. 35-47 (in Polish)

Antoszczyszyn, T. and Michalska, A. 2016. The potential risk of environmental contamination by mercury contained in Polish coal mining waste. Journal of Sustainable Mining Vol. 15, Issue 4, pp. 191-196.

Bielowicz, B. and Misiak, J. 2016. Siarczki w pokładach węgla kamiennego warstw orzeskich s.s. serii mułowcowej (westfal B) we wschodniej części GZW. Gospodarka Surowcami Mineralnymi-Mineral Resources Management Vol. 32, Issue 3, pp. 23-38 (in Polish).

Bojakowska, I. and Sokołowska, G. 2001. Rtęć w kopalniach wydobywanych w Polsce jako potencjalne źródło zanieczyszczenia środowiska. Biuletyn Państwowego Instytutu Geologicznego Vol. 394, pp. 5-54 (in Polish).

Bzowski, Z. and Dawidowski, A. 2013. Monitoring właściwości fizykochemicznych odpadów wydobywczych pochodzących z kopalni węgla kamiennego LW „Bogdanka”. Zeszyty Naukowe Uniwersytetu Zielonogórskiego No 149, Inżynieria środowiska No 29, pp. 87-96 (in Polish).

Chmielniak et al. 2012 - Chmielniak, T., Misztal, E., Kmieć, M. and Mazurek, I. 2012. Rtęć w węglach stosowanych w polskim sektorze energetycznym. Wydawnictwo Górnicze Karbo No 3, pp. 154-163 (in Polish).

Chmielniak, T. and Łukowicz, H. 2012. Wysoko sprawne ,zero-emisyjne” bloki węglowe zintegrowane z wychwytem $\mathrm{CO}_{2}$ ze spalin. Polityka Energetyczna - Energy Policy Journal Vol. 15, Issue 3, pp. 91-106 (in Polish).

Dai et al. 2006 - Dai, S., Ren, D., Chou, C.-L., Li, S. and Jiang, Y. 2006. Mineralogy and geochemistry of the No. 6Coal (Pennsylvanian) in the Junger Coalfield, Ordos Basin, China. International Journal of Coal Geology Vol. 66, pp. 253-270

Diehl et al. 2004 - Diehl, S.F., Goldhaber, M.B. and Hatch, J.R. 2004. Modes of occurrence of mercury and other trace elements in coals from the warrior field, Black Warrior Basin, Northwestern Albabama. International Journal of Coal Geology Vol. 59, pp. 193-208.

Dubiński, J. and Turek, M. 2012. Szanse i zagrożenia rozwoju górnictwa węgla kamiennego w Polsce. Wiadomości Górnicze No 11, pp. 626-633 (in Polish).

Dziok et al. 2014 - Dziok, T., Strugała, A., Rozwadowski, A., Górecki, J. and Ziomber, Z. 2014. Zmiany zawartości rtęci w węglu kamiennym w procesie jego wzbogacania. Polityka Energetyczna - Energy Policy Journal, Vol. 17, Issue 4, pp. 277-288 (in Polish) 
Dziok et al. 2015 - Dziok, T., Strugała, A., Rozwadowski, A., Macherzyński, M. and Ziomber, S. 2015 - Rtęć w odpadach z procesu wzbogacania węgli kamiennych. Gospodarka Surowcami Mineralnymi-Mineral Resources Management Vol. 31, Issue 1, pp. 107-122 (in Polish).

Dziok, T. and Strugała, A. 2017. Method selection for mercury removal from hard coal. E3S Web of Conferences, 14, 02007. [Online] Available at: e3s-conferences.org [Accessed: 3.10.2017].

Feliks, J. 2012. Performance tests of waste coal sludge granulation. Polish Journal of Environmental Studies Vol. 21, No. 5A, pp. 69-72.

Galos, K. and Szlugaj, J. 2010. Skały przywęglowe w górnictwie węgla kamiennego - odpady czy kopaliny towarzyszące? Górnictwo Odkrywkowe Vol. 51, No 2, pp. 25-31 (in Polish).

Galos, K. and Szlugaj, J. 2014. Management of hard coal mining and processing wastes in Poland. Gospodarka Surowcami Mineralnymi-Mineral Resources Management Vol. 30, Issue 4, pp. 51-61.

Gawlik, L. red. 2013. Węgiel dla polskiej energetyki w perspektywie 2050 roku-analizy scenariuszowe. Górnicza Izba Przemysłowo-Handlowa. Katowice: Wyd. IGSMiE PAN, 300 pp. (in Polish).

Grudziński, Z. 2012. Konkurencyjność paliw w wytwarzaniu energii elektrycznej. Polityka Energetyczna - Energy Policy Journal, Vol. 16, Issue 4, pp. 87-105 (in Polish).

Grudziński, Z. and Stala-Szlugaj, K. 2015. Wpływ emisji $\mathrm{CO}_{2}$ na koszty produkcji energii elektrycznej z węgla kamiennego. Annual Set The Environment Protection - Rocznik Ochrona Środowiska Vol. 17, pp. 1389-1402 (in Polish).

Hławiczka et al. 2001 - Hławiczka, S., Kubica, K., Zielonka, U. and Wilkosz, K. 2001. Właściwości emisji pyłu i metali ciężkich w procesie spalania węgla w paleniskach domowych. Archiwum Ochrony Środowiska Vol. 27, No. 2, pp. 29-45 (in Polish)

Jabłońska-Czapla et al. 2014 - Jabłońska-Czapla, M., Szopa, S. and Rosik-Dulewska, C. 2014. Impact of mining dump on the accumulation and mobility of metals in the Bytomka River sediments. Archives of Environmental Protection Vol. 40, Issue 2, pp. 3-19.

Jabłońska-Czapla et al. 2015 - Jabłońska-Czapla, M., Rosik-Dulewska, C., Szopa, S. and Zerzucha, P. 2015. Research into the metal/metalloid movements in soil and groundwater in the areas surrounding the coal waste dump Hałda Ruda (Upper Silesia, Poland). Rocznik Ochrona Środowiska (Annual Set The Environment Protection), Vol. 17, pp. 367-395.

Journal of Laws of 2002, No. 165, item 1359. Rozporządzenie Ministra Środowiska z dnia 9 września 2002 roku w sprawie standardów jakości gleby oraz standardów jakości ziemi (in Polish).

Journal of Laws of 2011, No 175, item 1048. Rozporządzenie Ministra Środowiska z dnia 15 lipca 2011r. w sprawie kryteriów zaliczania odpadów wydobywczych do odpadów obojętnych (in Polish).

Journal of Laws of 2016, item 1395. Rozporządzenie Ministra Środowiska z dnia 1 września 2016 r. w sprawie sposobu prowadzenia oceny zanieczyszczenia powierzchni ziemi (in Polish).

Kaliski et al. 2014 - Kaliski, M., Sikora, A.P. and Szurlej, A. 2014. Węgiel kamienny w polityce energetycznej Polski. Polityka Energetyczna - Energy Policy Journal Vol. 17, Issue 3, pp. 7-18 (in Polish).

Kicińska, A. 2017. Health risk assessment related to an effect of sample size fractions - methodological remarks. Stochastic Environmental Research and Risk Assessment. DOI: 10.1007/s00477-017-1496-7.

Klojzy-Karczmarczyk, B. 2014. Zmienność zawartości rtęci w poszczególnych frakcjach gruntów z otoczenia odcinka obwodnicy Krakowa. Rocznik Ochrona Środowiska (Annual Set The Environment Protection) Vol. 16, pp. 363-375 (in Polish).

Klojzy-Karczmarczyk, B. and Mazurek, J. 2013. Studies of mercury content in selected coal seams of the Upper Silesian Coal Basin. Gospodarka Surowcami Mineralnymi - Mineral Resources Management Vol. 29, Issue 4, pp. 95-106.

Klojzy-Karczmarczyk, B. and Mazurek, J. 2014. Badania zawartości rtęci i siarki w odpadach z obszaru nieczynnej hałdy odpadów górnictwa węgla kamiennego. Polityka Energetyczna - Energy Policy Journal Vol. 17, Issue 4, pp. 289-302 (in Polish).

Klojzy-Karczmarczyk et al. 2016a - Klojzy-Karczmarczyk, B., Mazurek, J. and Paw, K. 2016. Możliwości zagospodarowania kruszyw i odpadów wydobywczych górnictwa węgla kamiennego ZG Janina w procesach rekultywacji wyrobisk odkrywkowych. Gospodarka Surowcami Mineralnymi-Mineral Resources Management Vol. 32, Issue 3, pp. 111-134 (in Polish). 
Klojzy-Karczmarczyk et al. 2016b - Klojzy-Karczmarczyk, B., Mazurek, J., Staszczak, J., Mucha, J. and Paw, K. 2016. Ocena możliwości rekultywacji odkrywkowych wyrobisk poeksploatacyjnych z wykorzystaniem kruszyw ze skał towarzyszących pokładom węgla kamiennego na przykładzie ZG Janina. Górnictwo Odkrywkowe No. 5, pp. 23-33 (in Polish)

Klojzy-Karczmarczyk et al. 2016c - Klojzy-Karczmarczyk, B., Mazurek, J. and Mucha, J. 2016. Sulfur as a parameter in the suitability assessment of gangue from coal mining for reclamation of opencast excavation, taking into the requirements regarding protection of the soil. E3S Web of Conferences 10, 00036. [Online] Available at: e3s-conferences.org [Accessed: 3.10.2017].

Klojzy-Karczmarczyk et al. 2016d - Klojzy-Karczmarczyk, B., Mazurek, J. and Staszczak, J. 2016. Analiza jakości odpadów z nieczynnej hałdy górnictwa węgla kamiennego w odniesieniu do wymagań stawianych odpadom wydobywczym obojętnym. Zeszyty Naukowe - Bulletin of the Mineral and Energy Economy Research Institute of the Polish Academy of Sciences Issue 95, pp. 227-242 (in Polish).

Kosa, B. and Kicińska, A. 2016. Coal from the waste disposal site of the Siersza mine (Trzebinia, Poland) and its properties as a possible alternative fuel. E3S Web of Conferences 10, 00039. [Online] Available at: e3s-conferences.org [Accessed: 3.10.2017]

Kowalik M. and Zajemska M. 2013. Spalanie węgla kamiennego w powietrzu wzbogaconym tlenem a zanieczyszczenia. Polityka Energetyczna - Energy Policy Journal, Vol. 16, Issue 2, pp. 85-101 (in Polish).

Lorenz, U. 2005. Skutki spalania węgla kamiennego dla środowiska przyrodniczego i możliwości ich ograniczania Szkoła Eksploatacji Podziemnej. Sympozja i Konferencje No. 64, publisher MEERI PAS, pp. 97-112 (in Polish).

Malczyk, P. and Długosz, L. 2009. Zmienność przestrzenna całkowitej zawartości rtęci w poziomie powierzchniowym gleb wybranego obszaru Równiny Sępopolskiej. Ochrona Środowiska i Zasobów Naturalnych No. 40, pp. 39-48 (in Polish).

Mazur et al. 2004 - Mazur, M., Szczygłowski, P., Oleniacz, R. and Dańko, J. 2004. Emisja rtęci z energetycznego spalania węgla. Emisje - Zagrożenie - Ochrona powietrza, pp. 195-202. [Online] Available at: https://works.bepress.com/robert_oleniacz/79/) (in Polish).

Michalska, A. and Białecka, B. 2012. Zawartość rtęci w węglach i odpadach górniczych. Prace Naukowe GIG. Górnictwo i Środowisko Vol. 3, pp.73-87 (in Polish).

Mucha et al. 2016 - Mucha, J., Klojzy-Karczmarczyk, B. and Mazurek, J. 2016. Methodology of statistical study of the chemical composition of by-products of coal mining to assess their suitability as materials for reclamation. Gospodarka Surowcami Mineralnymi - Mineral Resources Management Vol. 32, Issue 4, pp. 73-90.

Okońska et al. 2013 - Okońska A., Uruski, Ł., Górecki, J and Gołaś, J. 2013. Metodyka oznaczania zawartości rtęci całkowitej w węglach energetycznych. Gospodarka Surowcami Mineralnymi - Mineral Resources Management Vol. 29, Issue 2, pp. 39-49 (in Polish).

Olkuski et al. 2010 - Olkuski, T., Ozga-Blaschke, U. and Stala-Szlugaj, K. 2010. Występowanie fosforu w węglu kamiennym. Gospodarka Surowcami Mineralnymi-Mineral Resources Management Vol. 26, Issue 1, pp. 23-35 (in Polish)

Różycka, K. and Rolka, G. 2015. Zastosowanie techniki ASA do oznaczania rtęci na przykładzie badań surowców używanych w przemyśle materiałów budowlanych. Prace ICiMB No. 21, pp. 58-66 (in Polish).

Smoliński ,A. 2007. Energetyczne wykorzystanie węgla źródłem emisji rtęci - porównanie zawartości tego pierwiastka w węglach. Ochrona powietrza i problemy odpadów No. 2 (238), pp. 45-53, (in Polish).

Stala-Szlugaj, K. 2011. Spalanie węgla kamiennego w sektorze komunalno-bytowym - wpływ na wielkość „niskiej emisji”. Rocznik Ochrona Środowiska (Annual Set The Environment Protection) Vol. 13, pp. 1877-1889 (in Polish).

Szczerbowski, R. and Ceran, B. 2017. Development perspectives of the Polish power generation sector according to the climate preservation conference COP21 policies. E3S Web of Conferences 14, 01003. [Online] Available at: e3s-conferences.org [Accessed: 3.10.2017].

Wichliński et al. 2011 - Wichliński, M., Kobyłecki, R. and Bis, Z. 2011. Emisja rtęci podczas termicznej obróbki paliw. Polityka Energetyczna - Energy Policy Journal Vol. 14, Issue 2, pp. 191-203 (in Polish).

Wichliński et al. 2012. Wichliński, M., Kobyłecki, R., Bis, Z. 2012 - Przegląd metod ograniczenia emisji rtęci w elektrowniach podczas spalania paliw stałych. Polityka Energetyczna - Energy Policy Journal Vol. 15, Issue 4, pp. 151-160 (in Polish). 
Wichliński et al. 2013a - Wichliński, M. Kobyłecki, R. and Bis, Z. 2013. The investigation of mercury contents in polish coal samples. Archives of Environmental Protection Vol. 39, No. 2, pp. 141-150.

Wichliński et al. 2013b - Wichliński, M., Kobyłecki, R. and Bis, Z. 2013. Wybrane metody oznaczania zawartości rtęci w węglach i popiołach lotnych. Polityka Energetyczna - Energy Policy Journal Vol. 16, Issue 3, pp. 287-299 (in Polish).

Wichliński et al. 2016 - Wichliński, M., Kobyłecki, R. and Bis, Z. 2016. Badania zawartości rtęci w mułach węglowych. Polityka Energetyczna - Energy Policy Journal Vol. 19, Issue 4, pp. 115-124 (in Polish).

Zajusz-Zubek, E. and Konieczyński, J. 2014. Coal cleaning versus the reduction of mercury and other trace elements' emissions from coal combustion processes. Archives of Environmental Protection Vol. 40, Issue 1, pp. 115-127.

\section{RTEĆ WE FRAKCJACH ZIARNOWYCH KRUSZYW I ODPADÓW WYDOBYWCZYCH GÓRNICTWA WĘGLA KAMIENNEGO}

Słowa kluczowe

górnictwo węgla kamiennego, odpady wydobywcze, kruszywa, muły węglowe, frakcje ziarnowe, rtęć całkowita, rekultywacja

\section{Streszczenie}

Wydobycie węgla kamiennego jest ściśle związane z wytwarzaniem znaczących ilości odpadów wydobywczych, wymagających dalszego wykorzystania, uznanych w praktyce za odpad lub jako surowiec. Istotne jest zatem poszukiwanie kolejnych lub doskonalenie już istniejących metod zagospodarowywania materiału odpadowego. Badania przeprowadzone we wcześniejszych pracach wykazały, że istnieje możliwość uzyskania frakcji ziarnowej (klasy ziarnowej) o niskiej zawartości siarki, tak aby możliwe było zagospodarowanie jej w wyrobiskach wymagających rekultywacji poprzez wypełnienie. Celem badań przedstawionych w prezentowanej pracy jest natomiast określenie zawartości rtęci w produktach ubocznych wydobycia węgla kamiennego. Występowanie rtęci w materiale odpadowym jest znane i udokumentowane w literaturze. Istotny jest jednak poziom zawartości tego pierwiastka w kruszywach czy odpadach. W prezentowanej pracy określono wymiary minimalne dla frakcji materiału skalnego spełniającej określone wartości graniczne pod kątem zawartości rtęci, powyżej której materiał można uznać za bezpieczny, jako kruszywo przeznaczone do wypełnienia wyrobisk poeksploatacyjnych. Dla wszystkich pobranych i wydzielonych próbek oznaczono zawartość całkowitą rtęci z zastosowaniem klasycznej metody absorpcji atomowej (analizator AMA-254 firmy Altec). Oznaczano zawartość rtęci całkowitej w próbkach w stanie analitycznym $\left(\mathrm{Hg}^{\mathrm{a}}\right)$. Badaniami laboratoryjnymi objęto materiał odpadowy bezpośrednio z produkcji (wydobycia i przerobu materiału skalnego) z jednej z kopalń węgla kamiennego GZW. Analizie poddano muły węglowe (po odwadnianiu na prasach filtracyjnych) oraz łącznie 13 prób kruszywa, po czym rozdzielono je na 15 frakcji ziarnowych. Zastosowana w pracy metoda oznaczania rtęci pozwoliła na wykazanie jej zawartości w mułach węglowych na poziomie od 0,0568 do $0,0787 \mathrm{mg} / \mathrm{kg}$, średnio przyjmując wartość $0,0649 \mathrm{mg} / \mathrm{kg}$ (średnia wilgotność próbek 4,3\%). Natomiast analiza zawartości całkowitej rtęci we wszystkich frakcjach wydzielonych z pobranych 13 prób kruszyw wykazała wysokie zróżnicowanie zawartości tego pierwiastka, przy czym zaobserwowano zdecydowaną tendencję zmniejszania 
zawartości rtęci wraz ze wzrostem wielkości ziaren. Wartości średnie zawartości całkowitej rtęci zmniejszają się od $0,4030 \mathrm{mg} / \mathrm{kg}$ dla frakcji najdrobniejszej $(0-6 \mathrm{~mm})$ do $0,0291 \mathrm{mg} / \mathrm{kg}$ dla frakcji najgrubszych (120-200 mm) (wilgotność próbek kruszyw około 1\%). Generalnie można stwierdzić, że przebadane próbki mułów węglowych oraz frakcji ziarnowych kruszyw spełniają kryteria stawiane odpadom wydobywczym obojętnym w odniesieniu do zawartości rtęci. Na podstawie przeprowadzonych badań można stwierdzić, że ze względu na obecność rtęci nie ma konieczności wydzielania frakcji drobnych z kruszyw. Jednak usunięcie z odpadowego materiału skalnego frakcji poniżej $8 \mathrm{~mm}$ zdecydowanie podnosi jakość materiału. Uzyskane wyniki badań oraz przeprowadzona analiza statystyczna jednoznacznie wskazują na silne wzajemne powiązanie występującej rtęci oraz siarki całkowitej w materiale (współczynnik determinacji liniowej $\mathrm{R}^{2}$ wynosi 0,9151 ), w którym jeszcze nie miały miejsca procesy wietrzeniowe. $\mathrm{W}$ przypadku badania materiału zwietrzałego brak jest jednak korelacji pomiędzy występowaniem rtęci i siarki, co może wynikać z odmienności procesów decydujących o przemianach i migracji związków rtęci i siarki.

\title{
MERCURY IN GRAIN SIZE FRACTIONS OF AGGREGATES AND EXTRACTIVE WASTE FROM HARD COAL MINING
}

\author{
Keywords \\ hard coal mining, extractive waste, aggregates, coal sludge, \\ grain size fractions, total mercury, reclamation
}

Abstract

Hard coal production is closely linked to the generation of significant quantities of extractive waste that require further use, in practice recognized as waste or as a raw material. It is therefore important to seek further or improve existing methods of waste material management. Studies conducted in earlier works have shown that it is possible to obtain a low-sulfur grain size fraction (grain class) so that it can be used in excavations requiring reclamation by filling. The purpose of the research presented in this paper is to determine the mercury content in hard coal mining by-products. The presence of mercury in the waste material is known and documented in the literature. However, the level of the content of this element in aggregates or wastes is important. This paper presents the problem of determining the minimum size of rock fractions meeting the specified limits for mercury content above which the material can be considered as safe are used to fill post-mining excavations. The total mercury content was determined using the classical atomic absorption method for all the collected and isolated samples (Altec AMA-254 analyzer). The total mercury content of the samples in the analytical state $\left(\mathrm{Hg}^{\mathrm{a}}\right)$ was determined. Laboratory research included waste material directly from production (mining and processing of rock) from the one of the hard coal mine USCB. Coal sludge (silt) (after dewatering on filter presses) and 13 aggregates samples were analyzed, and then separated into 15 grain size fractions. The mercury determination method used in the study allowed its content in the range of 0.0568 to $0.0787 \mathrm{mg} / \mathrm{kg}$, on an average mean of $0.0649 \mathrm{mg} / \mathrm{kg}$ (average moisture of the samples $-4.3 \%$ ). On the other hand, the total mercury content of all the fractions extracted from 13 samples of aggregates showed a high variability in the content of this element, with a noticeable 
tendency of decreasing mercury content along with the increase in grain size. The average values of the total mercury content decrease from $0.4030 \mathrm{mg} / \mathrm{kg}$ for the finest fraction $(0-6 \mathrm{~mm})$ to $0.0291 \mathrm{mg} / \mathrm{kg}$ for the thickest fraction $(120-200 \mathrm{~mm}$ ) (aggregate sample moisture at approximately $1 \%)$. In general, it can be stated that the analyzed samples of coal sludge and grain fractions of aggregates meet the criteria for inert mining waste with respect to the mercury content. Based on the studies conducted, it can be concluded that due to the presence of mercury there is no need to discard fine fractions from aggregates. However, the removal of waste rock material less than $8 \mathrm{~mm}$ significantly increases the quality of the material. The obtained results and the statistical analysis clearly indicate a strong correlation between the occurrence of mercury and total sulfur in the material ( $\mathrm{R}^{2}$ linear coefficient of determination at 0.9151), where no weathering has yet occurred. In the case of weathering, however, there is no correlation between the occurrence of mercury and sulfur, which may be due to the differences in the processes that govern the transformation and migration of mercury and sulfur compounds. 
